\title{
SOME ASPECTS CONCERNING THE COMMUNICATION IN MULTINATIONAL CORPORATIONS EXISTING ON THE ROMANIAN MARKET
}

\author{
Monica NIŢĂ, Radu D. STANCIU \\ Politehnica University of Bucharest, Romania \\ moniknita@yahoo.com, radu.stanciu@upb.ro
}

\begin{abstract}
The proposed topic presents a high interest at least from two points of view. Economically speaking, the multinational corporations define to a considerable extent the economic performance of Romania. As communication, these corporations with entire or prevailing foreign capital could be considered as models for what it means intercultural communication and cultural adapting. The research of the aspects connected to communication in an intercultural framework allows the drawing of some pertinent conclusions concerning the role of communication as a key factor of success or on the contrary an important barrier. At the same time, the approach of communication process needs not only the study of communication itself but also the mentalities, the attitudes, and the behaviors. The present paper refers mostly to internal communication and less to promotional communication. In the same time, it refers to the way act the organizational cultures existing in those corporations, if there is a closed connection between communication and organizational culture.
\end{abstract}

\section{Keywords: internal communication, multicultural, multinational corporations}

\section{Introduction}

The approach to communication within the multinational corporations on the Romanian market needs the focus on at least two aspects: place and role of those companies in the national economy, on one hand, and, from the point of view of communication, culture, and cultural adaptation, on the other.

In the same time, the analysis of communication process in an intercultural context calls for a study not only of verbal and nonverbal communication but also of mentalities, attitudes, and behaviors.

In studying the communication process of a company, is necessary to analyses the feature of both internal and external communication (so-called promoting or marketing communication) of it.

It is important to understand, as well, the way the organizational culture acts, taking into consideration its strong relation with communication [1].
In addition, internal communication has a strong influence on the organizational climate [1].

\section{Overview of the multinational corporations on the Romanian market}

The late '90s represented the entrance of the multinational companies in Romania. That event brought many changes in the economic and social environment, especially regarding the labor market. In the same time, that presence contributed to the emergence of modern technologies, different processes and procedures, consistency, and pragmatism.

The most recent figures regarding the multinational companies in Romania, collected by the Romanian National Institute of Statistics within the Foreign Affiliates Statistics, were published in an annual report by National Bank of Romania in the autumn of 2016. The report shows that, from 450 thousand active companies 
in Romania, multinational companies stand for around 30 thousand (less than 7\%). The majority, 11.4 thousand companies, are in the service industry. While their weight in the total number of active companies is small, their impact on Romanian economy is very important $[2,3]$.

Nowadays, the companies with a majority or entirely foreign capital stand for more than $80 \%$ from the gross profit and the turnover, at least in industry, as resulted from latest economic studies and analysis on the economic performances of the most important companies in Romania made by The National Institute of Economic Forecasting of The Romanian Academy. Those figures sustained the report called "Romania Top 100 Companies" for 2011 to 2016 published by Finmedia, one of the most important companies in the market of economic publications [4, 5]. The most multinational companies are from European Union (71\%).

Taking into consideration companies' turnover and the origin of the capital, most of those companies are from Germany. Second comes France, then Austria. Significant percentages have also the companies originating in Italy, Holland, Cyprus, Great Britain, and Spain. Regarding the companies originating outside EU, most of them are from United States, Japan, and Russia [3].

In analyzing the communication inside the multinational companies, is interesting to look to their workforce. The largest number of multinational companies' employees are in industry (over 570 thousand, around 41.5\% from total number of employees from industry). In services, there are around 147 thousand $(21.5 \%$ from the employees in services), while in trade there are more than 180 thousand $(21.4 \%$ from total number of employees from trade domain). The least employees are in construction sector, 24 thousand and is $6.75 \%$ from the total number of employees from tat sector [2,3].

Over $79 \%$ of the employees (810 thousands) are in multinational companies originating in EU, while in the companies outside EU work more than 211 thousand employees $(20,7 \%$ from total number of employees) [2,3].

\section{Intercultural dimension of communication in the multinational corporations}

The multinational corporations are important actors in the world economy. There are big companies, present in many countries, widespread all over the world through their subsidiaries or by mergers. The cultural spaces in which they run can be extremely varied and different. The personnel of those companies are heterogeneous from many points of view. Here is why, the communications problems are more delicate and complex.

Therefore, the approach of the communication process at the level of multinational companies, including those on the Romanian market, refers to certain features of intercultural communication and negotiation, and emphasis the necessity of cultural adaptation.

Cultural adaptation refers to a process in which the elements of a system (in our case, the multinational company, and its subsidiaries) are oriented and go in a direction where the adaptation probability increase $[6,7]$.

As a response to diverse cultural environments, the cultural adaptation appears when the individuals a significant measure of compliance in the new cultural environment. At the same time, within the intercultural contacts, one may speak of the emergence of a "land border" called cultural exchange, founded also in Romania, and represented by a set of rules, traditions, customs, attitudes, behaviors belonging to one part, specific for one culture that neither side will follow accurately, to achieve an easier rapprochement [7].

The culture influences both verbal (through spoken language) and nonverbal communication. Oral communication, used when there is a high cultural context, allows a greater closeness between people, a better knowledge of the way of thinking, trust, 
credibility, morality, creating a communication link before starting to talk business [1].

In written communication, specific for a lower influence of cultural context, the emphasis is on written documentation, rigor, and pragmatism founded especially in "cold" cultures.

Non-verbal communication must be carefully studied because its impact is much more important than verbal communication. People belonging to diverse cultures may have different gestures and facial expressions and may different in terms of body language, dressing code, how time is perceived, social distances, etc.

The differences in values and beliefs, mentality, attitudes generate the so-called intercultural communication barriers because there are harder to spot and harmonize.

Factors like how perceived good and evil, relations between men and women, how time is perceived, which traditions are considered important, the way to show respect, prejudices, attitudes towards other cultures, etc. may generate one of the barriers most important and elusive, differences in perception. The communication style may vary from one direct, clear, and concise to an indirect, roundabout and with nuances of meaning, hesitant one.

In this sense, very important is the knowledge of the cultural features of employees who come from other cultures and, on this basis, the development of empathy. Multinational and intercultural teams must work together to combine their efforts to obtain the best results.

In terms of "global communication" of these companies it is necessary to analyse the aims, principles, and philosophy declared by them. These principles must be included in all messages transmitted to assure image consistency and to achieve maximum impact on communication. Messages can be transmitted mainly through advertising and public relations.

Table 1 presents some examples of principles, goals, philosophies states be such companies that run on the Romanian market.

Table 1 Values and principles promoted in multinational corporations

\begin{tabular}{|l|l|l|}
\hline \multicolumn{1}{|c|}{ Company } & \multicolumn{1}{|c|}{ Values } & \multicolumn{1}{c|}{ Principles } \\
\hline $\begin{array}{l}\text { Kaufland } \\
\text { Romania }\end{array}$ & $\begin{array}{l}\text { Fairness and respect for } \\
\text { clients, employees, and } \\
\text { partners }\end{array}$ & $\begin{array}{l}\text { Focused on client satisfaction. } \\
\text { A better price/quality ration } \\
\text { Fairness for each employee } \\
\text { Compliance with legislation in force and internal } \\
\text { regulations }\end{array}$ \\
\hline $\begin{array}{l}\text { Carrefour } \\
\text { Romania }\end{array}$ & $\begin{array}{l}\text { A better life-quality } \\
\text { every day } \\
\text { Dedication, } \\
\text { responsibility, optimism }\end{array}$ & $\begin{array}{l}\text { Solidarity - financial and logistical support for } \\
\text { social programs } \\
\text { Care for environment - sustainable development } \\
\text { Attention to human relations } \\
\text { Development of close ties with domestic producers }\end{array}$ \\
\hline ArcelorMittal & $\begin{array}{l}\text { Nothing is more } \\
\text { important than } \\
\text { employees' health and } \\
\text { life }\end{array}$ & $\begin{array}{l}\text { Including labor health and safety in any decision } \\
\text { process } \\
\text { Personnel development } \\
\text { Environment protection }\end{array}$ \\
\hline $\begin{array}{l}\text { Procter \& } \\
\text { Gamble }\end{array}$ & $\begin{array}{l}\text { Integrity, Leadership, } \\
\text { for Success, and Trust }\end{array}$ & $\begin{array}{l}\text { Company's and individual interests are } \\
\text { inseparable. } \\
\text { Respect for everyone } \\
\text { Innovation is the cornerstone for success; } \\
\text { Outwards orientation } \\
\text { Be the best }\end{array}$ \\
\hline
\end{tabular}




\begin{tabular}{|l|l|l|}
\hline \multicolumn{1}{|c|}{ Company } & \multicolumn{1}{|c|}{ Values } & \multicolumn{1}{c|}{ Principles } \\
\hline $\begin{array}{l}\text { Orange } \\
\text { Romania }\end{array}$ & $\begin{array}{l}\text { Creativity, Audacity, } \\
\text { Dynamism, Care of the } \\
\text { details, Consistency, } \\
\text { Courage }\end{array}$ & $\begin{array}{l}\text { Communication - listen and keep balance in } \\
\text { everything you do } \\
\text { Integrity - be correct and fair in everything you do } \\
\text { Take any necessary measurements to avoid } \\
\text { conflicts } \\
\text { Stay out of politics }\end{array}$ \\
\hline $\begin{array}{l}\text { Oriflame } \\
\text { Romania }\end{array}$ & $\begin{array}{l}\text { Beauty, Dedication, } \\
\text { Passion, Solidarity, } \\
\text { Spirit - positive attitude }\end{array}$ & $\begin{array}{l}\text { Respect for people and nature; } \\
\text { Direct communication } \\
\text { Support for personal and professional } \\
\text { development } \\
\text { Community involvement } \\
\text { Manufacturing natural products. }\end{array}$ \\
\hline $\begin{array}{l}\text { Coca- Cola } \\
\text { Romania }\end{array}$ & $\begin{array}{l}\text { Innovation, Passion, } \\
\text { Integrity, Attitude of a } \\
\text { Leader }\end{array}$ & $\begin{array}{l}\text { Leadership in costs } \\
\text { Teamwork } \\
\text { Integrating the principals of sustainable } \\
\text { development into the decision-making process } \\
\text { Social partnership }\end{array}$ \\
\hline $\begin{array}{l}\text { Metro Cash \& } \\
\text { Carry Romania }\end{array}$ & $\begin{array}{l}\text { Added value gives } \\
\text { clients Efficiency and } \\
\text { Creativity Employees are } \\
\text { the most valuable } \\
\text { resource of the company }\end{array}$ & $\begin{array}{l}\text { Excellence in the supply chain management } \\
\text { Outstanding innovation and performance at } \\
\text { competitive prices. }\end{array}$ \\
\hline
\end{tabular}

4. Aspects regarding the internal communication within the multinational corporations on the Romanian market

Working in a multinational is the dream of many young Romanian graduates of college (one or more), or of one or more Master programs. Many of them do not know exactly what they expected: large volume of work (overtime hours), pace, prolonged stress, adaptation cumbersome due intercultural context.

Young people can have a successful upward career, a "brilliant career". On the other hand, in a multinational company is possible that this is only a myth. In fact, the place and role of everyone in the company are defined, the potential for each job is well designed and decided, and everyone's career path is predetermined. Therefore, the expectations of many employees (especially those with a solid, talented, and creative background) can be well above what companies will offer.

Professional advancement and salary increase do not come when expected. The rewards for young people can sometimes consist of training abroad, most often not followed by a promotion or raise.

In addition, other elements may have an impact on communication, culture, and organizational climate. Some of them have a positive connotation, some not.

Often, companies working on the principle of outsourcing, which means, among other things, that the Romanian employees will do the same thing with their foreign colleagues, but for much lower wages.

Then, investing in people is well timed, the induction training must cover all requirements of the post because they consider the possibility that the employee will leave the company after six months. It is intended that the adaptation period to be 
as short as possible and many things to be learned on the fly in a fast pace.

Most employees are young graduates or fresh employees. At the beginning, their wages are higher than in the public sector or in Romanian companies from the private sector, but in time, or even in case of a promotion, there are not important increases in wages.

Those companies focus on cost cutting and profit increasing because the performance of managers will be appraise based on these aspects.

In addition to their parent company, multinational corporations have offices in other countries, so Romanians may have colleagues in countries like England, France, Germany, the US, or even more remote countries of North Africa, Asia, etc.

The line managers for Romanian employees are also Romanian but the top management is foreign.

There are meetings for activity analysis where those involved are informed of the performance indicators. Information is oriented on past activity and are not communicated future goals and projects.

Many times, there is no transparency or honesty, and may appear games for satisfying unofficial interests. The work environment can often be bureaucratic, especially in terms of decision-making.

In the same time, risk control and focus attention on results makes human resources to be secondary.

In addition, the working environment organization is a "desk near desk" type, and employees must adapt to a situation that does not respect the personal space.

Talking only about the advantages of having a job in a multinational company, they refer to but not limited to the following aspects:

- A higher salary and a bonus system different from those existing in Romanian companies;

- Private health insurance usually included salary offer;

- Possibility of specific training abroad;
- Possibility of posting in other foreign subsidiary, seen as a promotion;

- Ability to approach a set of values and models that are relevant to employees not only professionally, but also in terms of personal development;

- There is the opportunity to develop in a multicultural environment that broadens the horizon of thought.

The official language in most companies is English. Exceptions are the German or Austrian companies who claim knowledge of the German language. For Romanian employees, English language is not a barrier to communication

The "business" language used by the Romanian employees is a mixture of English terms with Romanian language, so cold "Romgleza", that tend to replace the Romanian language in many companies especially in IT marketing/advertising, and management.

More than their foreign colleagues, Romanians put price on interpersonal relationships at work and less on their professional goals. For example, they talk "too much" comparing to Western employees, about themselves and about others.

Communication between employees and management (middle and top) is mostly indirect, through a designated person or email. Many meeting are "virtual", by using telephone or intranet. They are used to discuss topics referring mainly to figures or to give orders, etc.

Given the less enjoyable experiences of Romanians working in multinational companies, some negative manifestations related to communication like gossip and any verbal attack against someone, especially when is not present, disrupting a supervisor especially when making observations, refusing a task without tact, promising something before understanding exactly what it is, deadlines noncompliance, etc. must be avoided. 


\section{Conclusions}

The aspects presented in this paper and many more others not explicitly presented because of space limitation, led to some conclusions.

In the business space of the multinational companies, local cultural values approaching increasingly more European ones, since the clear majority of the companies comes from Europe.

To have a communication process, a multinational company must cultivate a range of values that transcend individual cultures within it, as the quality of intercultural communication depends on how everyone in the organization understand and accept cultural differences. So, one may speak of a "cultural exchange" process.

Intercultural communication problems within multinational companies in Romania are not related to the official foreign language spoken. They deal with the mentality, attitudes, behaviors, and management system.

The multinational companies have no special preoccupations on how communication works and how motivated are employees. They focus on outcomes and profit.

Even if how communication works reflect the economic performance and the organizational culture and organizational climate, this is not fully realized in most companies.

\section{References}

[1] Niţă, M., Stanciu, R.D., Annals of the Oradea University, Fascicle of Management and Technological Engineering, Vol. XXIV (XIV), No. 1, pp. 105-108, 2015.

[2] Banca Naţională a României, Investițiile străine directe în România în anul 2015. [pdf], Available at http://www.bnr.ro/PublicationDocuments.aspx?icid=9403 [accessed March 2017].

[3] http://economie.hotnews.ro/stiri-finante banci-21600876-isarescu-multinationalele-trebuieintre-legislatia-romaneasca-respecte-fiscalitatea-regulile-noastre-cate-multinationale-suntfapt-romania-afaceri-deruleaza-cati-angajati.htm [accessed March 2017].

[4] http://www.zf.ro/banci-si-asigurari/s-a-schimbat-liderul-top-100-cele-mai-valoroasecompanii-din-romania-hidroelectrica-devine-pentru-prima-data-cea-mai-valoroasacompanie-din-romania-devansand-omv-petrom-16005049 [accessed February 2017].

[5] http://www.piatafinanciara.ro/top-1000-companii-dupa-cifra-de-afaceri-pe-2015/ [accessed February 2017]

[6] Niță, M., Organizational Culture and Entrepreneurial Spirit: Romania vs Germany, Proceedings of the $3^{\text {rd }}$ Review of Management and Economic Engineering International Management Conference, pp. 79-85, Cluj-Napoca, Romania, September 2012.

[7] Niţă, M., Aspects of The Organizational Culture in The Multinational Companies in Romania, Proceedings of the $6^{\text {th }}$ International Conference of Management and Industrial Engineering, Management - Facing New Technology Challenges, pp. 307-313, Bucharest, Romania, October 2013. 